\title{
PERAN SYSTEM INFORMASI MANAJEMEN DALAM PENGAMBILAN KEPUTUSAN FADLI JERIKO
}

\author{
Prodi system informasi, fakultas sains dan teknologi \\ Fadlijeriko20@gmail.com
}

\begin{abstract}
Abstrak
Dalam perkembangan zaman sekarang ini ,setiap organisasi atau lembaga sangat diperlikan diperlukan untuk menciptakan suatu sistem informasidan sumber daya manusia agar dalam pengembangan sistem informasi dapat mempengaruhi dari pengambilan suatu keputusan di dalamsuatu lembaga. Pengambilan keputusan diharapkan menjadi suatu proses menuju arah yang lebih baik sehingga denganpegetahuan yang dimiliki tentang sistem informasi manajemen, pertimbangan dan akhirnya diputuskan secara tepat. dikarenakan sebuah sistem informasi merupakan terdiri dari beberapa komponen-komponen yangpenting dari lembaga pendidikan guna untuk menyediakan beberapainformasi yang akan sangat dibutuhkan oleh para pengambil keputusan dalam melakukan kegiatan pendidikan
\end{abstract}

Kata Kunci: Pengambilan Keputusan, sumber daya manusia, Sistem Informasi Manajemen

\section{PENDAHULUAN}

Di zaman teknologi sekarang dapat dilihat teknologi itu sendiri yang sangat pesat dalam hal teknologi dan komunikasi. Perubahan tersebut menyebabkan setiap Organisasi untuk mampu menghadapi persaingan dengan sendiri. Kebutuhan manusia akan informasi amatlah penting Sejalan dengan perkembangan zaman Sekarang dapat kita lihat bahwa dalam proses pengelolaan sumber daya manusia secara efektif, setiap organisasi perlu menciptakan sistem informasi sumber daya manusia. 1 Oleh karena itu perkembangan sistem informasi akan dapat bersaty dengan adanya sumber daya manusia. 
dalam perubahan sangat perlu pengawasan dari seorang manajer

. Sehingga tetap perlu adanya seseorang yang memiliki kedudukan lebih

tinggi dari sumber daya manusia tersebut , maka perlu adanya manajer atau manusia itu sendiri yang

mengatur manajemen suatu lembaga dalam lembaga tersebut.

\section{STUDI LITERATUR}

Studi literatur yang bersumber dari jurnal, buku, makalah, skripsi dan internet, membaca dari beberapa sumber terpercaya, dan tentunya yang bersangkutan dengan sistem informasi manajemen

Sistem berasal dari bahasa Latin dan bahasa Yunani adalah kesatuan yang terdiri atas komponen atau elemen yang saling berkaitan untuk memudahkan aliran sebuah informasi, materi, dan energi untuk mencapai suatu tujuan.

\section{METODE PENELITIAN}

Di Dalam artikel ini bersifat peranan sistem informasi maanjemen dalam sebuah proyek. Dan terdapat beberapa tahap demi tahap yang dilalui seperti pengumpulan data, mencari informasi yang bersumber dari internet, majalah dah beberapa sumber terpercaya.

\section{Pengumpulan informasi}

Pengumpulan data umumnya dilakukan dengan menyebutkan fakta dan pertemuan yang dapat diamati. Dimana setiap kelompok akan segera turun ke lapangan untuk melihat bagaimana kerangka pameran dalam usaha tersebut.

\section{Pemeriksaan kebutuhan pemrograman}

Siklus ini mengumpulkan persyaratan untuk kerangka data sebagai informasi, interaksi yang terjadi dan hasil normal. 


\section{Rencana}

. Rcana Basis Data

Kumpulan data adalah bagian penting dari kerangka data karena berfungsi sebagai pusat distribusi penyimpanan informasi untuk persiapan tambahan.

Hasil penelitian

Sistem

Berikut beberapa pengertian sistem menurut beberapa ahli:

Ludwig Von Bertallanffy

menurut Ludwig Von Bertallanffy sistem merupakan suatu kumpulan unsur yang berada pada kondisi yang saling berkaitan satu sama lain.

\section{R. Fagen dan A.Hall}

menurut R. Fagen dan A.Hall sistem yaitu suatu kumpulan objek yang meliputi hubungan antara objek tersebut, serta hubungan antara sifat yang mereka punya.

Berdasarkan pendapat para ahli diatas maka dapat kita simpulkan bahwa pengertian sistem yaitu suatu kumpulan dari elemen-elemen yang saling berkaitan , beroperasi secara bersamasama untuk mencapai suatu tujuan tertentu.

\section{Teknologi informasi}

pengertian teknologi Informasi istilah umum dari teknologi untuk membantu manusia dalam $\mathrm{n}$ menyebarkan suatu informasi .

Teknologi informasi merupakan suatu teknologi yang memiliki fungsi mengolah data, memproses data, memperoleh, menyusun, menyimpan, mengubah data dengan segala macam cara untuk mendapatkan informasi yang bermanfaat. 


\section{Sitem informasi manajemen}

SIM merupakan sekumpulan proses yang dimana datanya dapatdiolah, dianalisis, dan ditampilkan supaya data tersebut menjadi sangat berguna untuk kebutuhan pengambilan keputusan. Sistem ini merupakan alat yang sangat berguna untuk dalammengendalikan operasi perusahaan.

Tujuan utama dari sistem yaitu untuk mengumpulkan dan mengatur semua data dari berbagai tingkat perusahaan, meringkas, kemudian memberikan fasilitas dan meningkatkan kualitas dari pengambilan keputusan untuk meningkatkan suatu produkdari perusahaan tersebut. sistem informasi manajemen campuran antara Sumber Daya Manusia dan teknologiinformasiguna untuk mengolah, dan mengambil kembali data dalam hal membantu dan mendukung suatu proses pengambilan keputusan di bidang tertentu. Bisa disebut pula bahwa sistem informasi manajemen yaitu sistem yang dirangkai untuk menyediakan suatu informasi untuk mendukung dalam pengambilan keputusan dalam disuatu organisasi kegiatan manajemen dalam suatu lembaga.

\section{Sumber daya manusia}

Sumber Daya Manusia merupakan seseorang yang bekerja sebagai penggerak suatu organisasi atau lembaga, yang berupa perusahaan yang berfungsi sebagai asset berharga yang harus dilatih dan dikembangkan kemampuannya untuk mencapai suatu tujuan .

Sumber daya manusia salah satu faktor yang sangat penting bahkan tidak dapat dilepaskan dari sebuah organisasi. SDM juga merupakan kunci dalam menentukan perkembangan suatu perusahaan. SDM bisa manusia yang diperlukan di sebuah organisasi sebagai pemimpin, dan sebagai pemikir untuk suatu rencana dalam suatu perusahaan unuk mencapai beberapa tujuan beberapa dari organisasi itu. 
Syaiful Bahri Jamarah berpendaoat Adapun komponen data SDM untuk meningkatkan SDM dalam mengembangkan suatu usaha yaitu

1). Kualitas pekerjaan

kualitas kerja adalah suatu hasil yang dapat diukur dengan efektifitas dan efisiensi suatu pekerjaan yang dilakukan oleh sumber daya manusia atau sumber daya lainnya dalam pencapaian tujuan atau sasaran perusahaan dengan baik dan berdaya guna. Inovatif yaitu Kemampuan seseorang dalam mendayagunakan kemampuan dan keahlian untuk menghasilkan karya baru.

2). Kejujuran karyawan dalam bekerja

Kejujuran Sangat berguna dalam bekerja dengan kejujuran kita akan selalu dipercaya dan dengan sikap jujur kita akna merasakan kehidupan yang lebih baik lagi . Pentingnya kejujuran dalam bekerja wajib kita terapkan sejak kecil agar ketika besar dan sudah bekerja kita dapat menjadi jujur dan insya Allah mendapatkan pekerjaan yang lebih baik .

3). Kehadiran dalam bekerja

Kehadiran absensi seorang karyawan sebagai sebuah hal yang sangat penting harus dilakukan kecuali ada hal-hal lain yang sifatnya penting dan hal tersebut dapat dipertanggung jawabkan oleh yang bersangkutan. kehadiran karyawan sudah ditentukan dan diatur dari perusahaan dan kemudian duterapkan di masing-masing bagian.

4). Sikap dalam bekerja

Sikap positif sangat diperlukan terutama jika kitaa mendapatkan masalah dalam pekerjaan kita. Jangan langsung putus asa tetapi berusaha mencari apa yang harus diperbaiki. Bisa jadi ini langkah untuk mencapai posisi yang lebih baik lagi kedepannya jadi harus tetap optimis . 


\section{5). Inisiatif dan kreatif}

Seseorang dapat dikatakan kreatif apabila diabisa membuat atau menciptakan sesuatu, baik itu dari hasil pemikiran sendiri ataupun dari masukasan orang lain , namun orang yang kreatif belum tentu inisiatif, Sedangkan seseorang yang bisa dikatakan mempunyai sikap inisiatif apabila dia bisa melakukan sesuatu tanpa yang tidak pernah orang lain lakukan, dan orang inisiatif selalu mengandalkan dirinya sendiri dalam melakukan sesuatu yang akan dia lakukan

Kerjasama dengan orang lain memang sangat diperlukan, karena dengan adanya kerjasama akan mempermudah kita dalam melakukan pekerjaan.

6). Keandalan dalam bekerja

Keandalan dalam menjaga pekerjaan berarti mampu menjalani kepatuhan terhadap prinsipprinsip moral dan etika kerja; mampu mengembangkan karakter diri yang taat moral dan etika; mampu menjaga kejujuran dan keikhlasan hati untuk berkontribusi terhadap kemajuan perusahaan, serta mampu membebaskan diri dari kontrol dan pengaruh negatif orang lain.

\section{7). Pengetahuan tentang pekerjaan}

Pengetahuan yang harus dimiliki oleh seorang tenaga kerja agar dapat melakukan kerja dengan wajar, Pengalaman kerja ini sebelum ditempatkan dan harus diperoleh pada ia bekerja dalam pekerjaan tersebut.

8). Tanggung jawab terhadap pekerjaan

Bertanggung jawab berarti kita harus menerima ketika kita melakukan kesalahan. Di dalam pekerjaan pasti selalu ada kesalahan yang akan kita lakukan dari situ kita harus menerima lalu meminta maaf dan memperbaiki diri untuk menatap masa yang akan datang. Dan dari kesalahan tersebut kita akan menjadi diri kita sendiri dan melatih mental. Di saat kita itulah kita akan menjadi diri kita menjadi orang yang bisa bertanggung jawab atas kesalahan. Hal tersebut 
agar rasa tanggung jawab yang telah kita kerjakan dapat berhasil dengan baik. Sehingga masalah itu kita dapat selesaikan dengan bijaksana.

9). Pemanfaatan waktu dalam bekerja

Waktu adalah uang, kata kata tersebut dapat kita jadikan sebagai acuan untuk nlebih bisa menghargai waktu namun lebih dari itu.maka dari itu kita harus lebih bisa mengatur waktu kita kapan harus bekerja kapan harus istirahat dan kapan harus bersantai.

Fungsi Pengelolaan Sumber Daya Manusia

Suderajat Cahyono mengatakan bahwa

a). Fungsi dari Tenaga Kerja

Fungsi pengadaan tenaga kerja meliputi kegiatan dan kebutuhan tenaga kerja , mencari sumber-sumber tenaga kerja yang bekerja secara efektif dan efisien, mengadakan seleksi terhadap para pelamar kerja, menempatkan tenaga kerja sesuai dengan posisi yang sesuai dengan keahliannya, dan memberikan pendidikan kepada tenaga kerja yang baru

b). Fungsi pemeliharaan tenaga kerja

Fungsi pemeliharaan tenaga kerja mencakup pelaksanaan program-program ekonomis maupun non-ekonomis, yang diharapkan dapat memberikan kenyamanan kerja bagi para pekerja, sehingga mereka dapat bekerja dengan tbaik dan penuh komitmen guna menghasilkan kerja yang diharapkan oleh suatu organisasi.

Tujuan Manajemen Sumber Daya Manusia 
Tujuan manajemen SDM adalah untuk menigkatkan suatu kontribusi produktif dari orangorang yang ada di dalam suatu perusahaan melalui beberapa cara yang bertanggung jawab secara strategis, etis, dan sosial. Selain itu, Tujuan dari pengembangan SDM adalah dapat ditingkatkannya kemampuan para pekerja, keterampilan dan sikap dari anggota organisasi sehingga lebih baik dalam mencapai tujuan organisasi.

\section{B Manfaat Pengelolaan Sumber Daya Manusia}

Sedangkan manfaat dan tujuan dari kegiatan pengembangan sumber daya manusia menurut Schuler yaitu :

a). Mengurangi dan menghilangkan kinerja yang buruk

Dalam hal ini kegiatan pengembangan akan meningkatkan kinerja pegawai saat ini, yang dirasakan kurang dapat bekerja secara efektif dan ditujukan untuk dapat mencapai efektivitas kerja sebagaimana yang diharapkan oleh organisasi.

b). Meningkatkan suatu produktivitas

Dengan mengikuti kegiatan pengembangan berarti pegawai juga memperoleh tambahan ketrampilan dan pengetahuan baru yang bermanfaat bagi pelaksanaan pekerjaan mereka. Dengan semikian diharapkan juga secara tidak langsung akan meningkatkan produktivitas kerjanya.

c). Meningkatkan keterampilan dari angkatan kerja

Dengan semakin banyaknya ketrampilan yang dimiliki pegawai, maka akan lebih fleksibel dan mudah untuk menyesuaikan diri dengan kemungkinan adanya perubahan yang terjadi dilingkungan organisasi. Misalnya bila organisasi memerlukan pegawai dengan kualifikasi tertentu, maka organisasi tidak perlu lagi menambah pegawai yang baru, oleh Karena pegawai yang dimiliki sudah cukup memenuhi syarat untuk pekerjaan tersebut. 


\section{d). Meningkatkan kesetiaan karyawan}

Dengan melalui kegiatan pengembangan, pegawai diharapkan akan memiliki persepsi yang baik tentang organisasi yang secara tidak langsung akan meningkatkan komitmen kerja pegawai serta dapat memotivasi mereka untuk menampilkan kinerja yang baik.

e). Mengurangi ketidakhadiran karyawan

Bahwa dengan semakin besarnya komitmen pegawai terhadap organisasi akan memberikan dampak terhadap adanya pengurangan tingkat turn over absensi. Dengan demikian juga berarti meningkatkan produktivitas organisasi.

Hubungan Sitem Informasi Manajemen dan Sumber daya manusia

Sistem informasi manajemen dipahami sebagai hubungan sub-sistem informasi yang menyeluruh dan terkoordinasi yang secara rasional mampu menstransformasikan data sehingga menjadi informasi dengan berbagai cara guna meningkatkan produktivitas yang sesuai dengan gaya dan sifat manajen.

Bila dikaitkan SIM dikaitkan dengan SDM, maka dapat dimaknai bahwa semakin baik SIM yang diterapkan maka akan semakin baik pula SDM yang tersedia, karena dapat mendeteksi berbagai kelemahan SDM yang ada baik dilihat dari kedisiplinan, kepemimpinan, kinerja, loyalitas, outpun yang bisa dihasilkan

Pentingnya Sumber Daya Manusia

SDM sangat lah penting peranannya Sebagai suatu organisasi yang bergerak dibidang jasa untuk meningkatkan kepuasan pelanggan, melalui beberapa sistem yang harus efektif, dan terus melakukan perbaikan pada semua proses yang ada. Agar semua proses berjalan dengan baik perlu ditunjang oleh sumber daya manusia, infrastruktur, dan lingkungan perkuliahan. Sumber daya manusia mencakup pimpinan, karyawan. Penyediaan sumber daya harus memadai baik dari sisi kualitas maupun kuantitas.

Banyak perubahan terjadi dalam lingkungan sumber daya manusia yang menuntutnya untuk memainkan peranan yang penting dalam suatu organisasi seperti perkembangan teknologi informasi yang pesat, globalisasi, dan perubahan dalam dunia jabatan kiyta dan kerja 


\section{Peran Sistem Informasi Manajemen dalam Pendidikan}

Fungsi dari sistem informasi manajemen untuk bidang pendidikan yaitutentang untuk menyediakan informasi tentang suatu organsasi baik berupa data data siswa, nilai siswa dan yang terutama dengan sekarang ini kita dapat menggunakan teknologi sebagai sarana pembelajaran guna untuk memudahkan kita dalam hal pekerjaan dan pengelolaan, perencanaan, dan pengawasan suatu organisasi.

SIM juga dapat memudahkan dalam hal prose pembelajaran karena dengan adanya system informasi akan menjadikan pembelajaran menjadi lebih efektif terutama ketika daring seperti sekarang ini.

\section{Kesimpulan}

Dalam pengambilan keputusan sangst perlu adanya pengaruh dari system informasi manajemen dikarenakan sangat penting suatu organisasi mempunyai seorang manajer yang dapat mengatur semua hal yang terjadi didalam suatu organisasi ataupun lembaga, tanpa adany pengaruh dari system informasi manajemen suatu organisasi tidak akan dapat berjalan dengan maksimal .

\section{DAFTAR PUSTAKA}

. http://oobelix7.blogspot.co.id/2012/1/kelebihan-dan-kekuranganmenggunakan.html diakses pada tanggal (10 Maret).

2. http://mandraputra.blogspot.com/2012/12/cara-menghubungkan-2-routerdengan-html diakses pada tanggal (20 April).

3. http://www.debian.or.id/tags/deboot rap diakses pada tanggal (1 Januari).

4. http://nesabamedla.com/cara-menginstall-windows-7/ diakses pada tanggal (5 Agustus).

5. http://dhamar-tkj.blogspot.com/2013/12/cara-configurasi-dua-router-dicisco.html diakses pada tanggal (18 April).

6. http://slidshare.com diakses pada tanggal (10 maret) 
7. http://andiblogspot.com/cara-menggunakan-aplikasi. Diakses pada tanggal (8 Juni)

8. http://cintablogspot.com. Diakses pada tanggal (3 Maret).

9. http://reynaldifauzi99.blogspot.co.id di akses pada tanggal (11 Januari).

10. http://www.lugi.org.id diakses pada tanggal ( 3 November). 